\title{
Sedimentology and stratigraphy of Neoproterozoic-lower Paleozoic carbonate-siliciclastic succession of the southwesternmost Amazon Craton, state of Rondônia, Brazil
}

\author{
Jhon Willy Lopes Afonso ${ }^{1 *}$, Afonso César Rodrigues Nogueira ${ }^{1}$
}

\begin{abstract}
Facies and stratigraphic analysis were carried out in Neoproterozoic-Lower Paleozoic carbonate-siliciclastic deposits of Cacoal and Pimenta Bueno formations exposed on basement rocks and into the Pimenta Bueno Graben, northwestern portion of Parecis Basin, southwesternmost Amazon Craton. The redescription and redefinion of this succession confirmed the previous interpretation for the Cacoal Formation as a Marinoan ( $-635 \mathrm{Ma})$ cap carbonate. The Cacoal Formation is subdivided here in two units separate by sharp contact found exclusively overlying Mesoproterozoic crystalline basement rocks: 1) a homonymous formation characterized by diamictites, sandstones and siltstones with dropstones interpreted as glacio-marine deposits; and 2) the Espigäo d'Oeste Formation that consists of dolostone, dolomitic stromatolites, dolostone-siltstone rhythmite and siltstone interpreted as shallow to moderately deep platform deposits. The Ordovician to Silurian Pimenta Bueno Formation is a filling of Pimenta Bueno graben and overlies locally the Meso and Neoproterozoic rocks. This unit consists in diamictites, sandstones, siltstones and pelites interpreted as glacial-marine and tide- to storm-influenced platform deposits, recording a glacio-eustatic regressive-transgressive event. This new stratigraphic proposal modify the current stratigraphy for the Parecis Basin and suggest, at least, two levels of glaciation exposed in the sothwesternmost Amazon Craton related to the Marinoan and Late Ordovician-Early Silurian events.
\end{abstract}

KEYWORDS: Pimenta Bueno Graben; Parecis Basin; Amazon Craton; stratigraphic redefition; Neoproterozoic.

\section{INTRODUCTION}

The more ancient sedimentary cover in the Southwesternmost Amazon Craton is represented by a carbonate-siliciclastic succession which overlies Precambrian crystalline basement rocks and fill the Pimenta Bueno Graben (PBG), a geotectonic feature linked to the evolutive history of the Paleozoic Parecis Basin (Fig. 1). This succession has been traditionally attributed to the Cacoal and Pimenta Bueno formations of Lower Paleozoic age (Siqueira 1989, Siqueira \& Teixeira 1993, Pedreira \& Bahia 2000, Pedreira \& Bahia 2004, Bahia et al. 2006, Bahia 2007). Originally, conglomerates and dolostones included in Cacoal Formation were described and interpreted, respectively, as alluvial fans and deltaic depositional system developed in rift-phase of the Paleozoic Parecis Basin (Bahia et al. 2006). However, Gaia et al. (2017) based on facies analysis, carbon isotope and correlation with previously carbonate occurrences in the State of Mato Grosso, Mid-western Brazil, the Cacoal Formation was reinterpreted as glacial and shallow to moderately deep platform deposits, which represent a Neoproterozoic cap carbonate linked to the Marinoan glacial event $(-635 \mathrm{Ma})$. In this new conception, Neoproterozoic Cacoal deposits represent a sedimentary cover of Amazon Craton completely disconnected of the Parecis Basin evolution.

Outcrop-based stratigraphic and facies analysis carried out in the Cacoal, Pimenta Bueno and Espigão d'Oeste regions, State of Rondônia, allowed the redescription

${ }^{1}$ Instituto de Geociências, Universidade Federal do Pará - UFPA, Belém (PA), Brazil. E-mails: jhon.afonso@ig.ufpa.br, nogueira@ufpa.br

*Corresponding author.

Manuscript ID: 20170002. Received on: 01/09/2017. Approved on: 10/31/2017. 
and redefinition of the carbonate-siliciclastic succession exposed in the Pimenta Bueno Graben, Northwestern portion of Parecis Basin, Southwesternmost Amazon Craton (Fig. 1). This analysis corroborates the proposal of Gaia et al. (2017) for the Cacoal Formation and subdivides this unit into:

a basal homonymous unit composed basically of diamictites and sandstone; and

- the Espigão d'Oeste Formation, that represents the cap dolomite following the formal definition in the context of Snowball Earth hypothesis (cf. Hoffman \& Schrag 2002, Nogueira et al. 2003).

The inference of Neoproterozoic age for the basal glaciogenic deposits and cap carbonate (Cacoal and Espigão d'Oeste formations) opens a discussion about the age for the overlaid glaciogenic deposits of the Pimenta Bueno Formation, previously considered as Carboniferous (Pedreira \& Bahia 2004, Bahia et al. 2006). The detailed stratigraphic and paleoenvironmental reconstitution proposed here indicate,

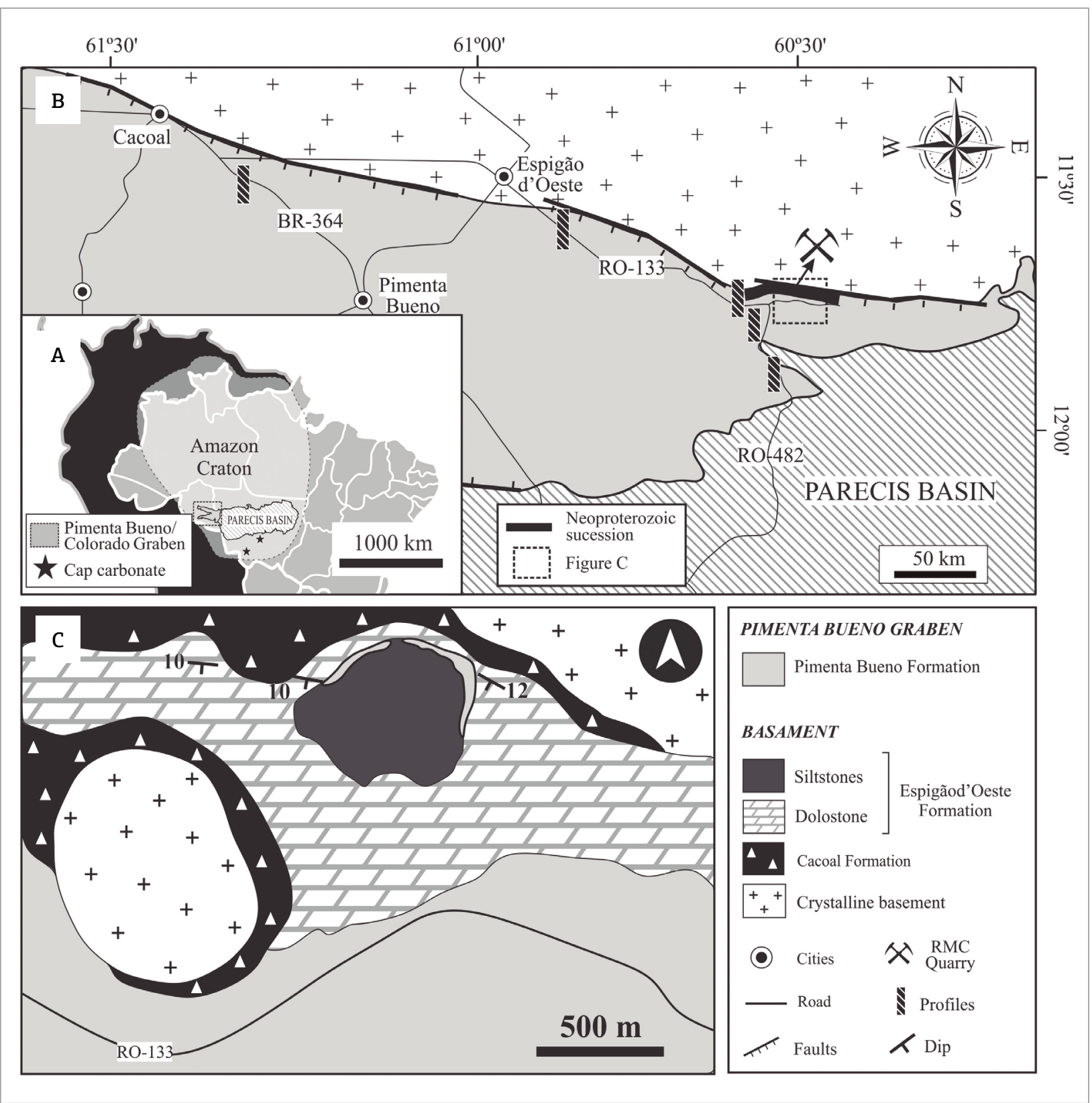

Figure 1. Geologic map of studied area. (A) Location of the Amazon craton and Neoproterozoic cap carbonate occurrences. (B) Pimenta Bueno Graben (PBG) showing sections studied and occurrences of Neoproterozoic cap carbonate sucessions generally overlying crystalline basement rocks. (C) Quarry of the Rondônia Mining Company - RMC quarry. 
at least, two glacial levels for the listhostratigraphy of the PBG and its basement, providing a better understanding of the evolutive history during the Late Neoproterozoic to Early Paleozoic in this part of the Amazon Craton.

\section{GEOLOGICAL SETTING AND STRATIGRAPHIC NOMENCLATURE}

The PBG together with the Colorado Graben form a distinct forked structure trending NW-SE and SW-NE restricted to the Northwestern Parecis Basin (Fig. 1). For decades, both grabens were included in the Rondonia sub-basin, belonging to the Paleozoic Parecis Basin, an intracratonic basin with approximately $500,000 \mathrm{~km}^{2}$, covering the central and north regions of the State of Mato Grosso and the eastern part of the State of Rondônia, Mid-western Brazil. The Parecis Basin is filled with Phanerozoic sedimentary deposits and, locally, volcanic rocks which unconformably overlie the Paleoproterozoic/Mesoproterozoic basement rocks of the Amazon Craton (Almeida 1983, Siqueira 1989, Tassinari \& Macambira 1999, Santos et al. 2000).

Stratigraphic proposals for PBG started in the late 1970's with the study by Pinto Filho et al. (1977), who distinguished three sequences informally nominated PCI, PCII and PCIII. Siqueira (1989) proposed, for the first time, a formal stratigraphic framework for the PBG that included, from base to the top, the Cacoal, Pimenta Bueno and Fazenda da Casa Branca formations. Caputo (1984) described the occurrence of foraminifera (fusulinids) in carbonate sediments above the Pimenta Bueno Formation and suggested a correlation with the Itaituba Formation (Solimóes/Amazonas Basin) and the Tarma Formation (Peru). However, this unit proposed by Caputo (1984) was never recognized in surface and subsurface investigation, and fossil data never was published and really confirmed.

The siliciclastic and carbonate rocks in the PBG were grouped by Scandalora et al. (1999) in the Primavera Group, but this term fell into disuse. The nomenclature suggested by Siqueira (1989) was kept on subsequent works (Bahia \& Pedreira 1996, Bahia et al. 1996, Pedreira \& Bahia 2000, 2004, Bahia et al. 2006). Rizzotto et al. (2004) used the name Rolim de Moura Formation in substitution to Cacoal Formation, due to the duplicity of name with the Intrusive Suite Cacoal. Recently, Quadros \& Rizotto (2007), based purely on lithological criteria, proposed the division of the Pimenta Bueno Formation, creating the Pedra Redonda Formation for the diamictites beds (Fig. 2). Although this new denominations simplifies the lithostratigraphic terms, it does not clarify a distinction between different diamictites, hindering a possible separation of glacial events. Nevertheless, at least two glacial levels have been described in the stratigraphy of Parecis Basin, with the one considered more ancient being Ordovician-Silurian age (Fig. 2). The previous lithostratigraphic studies of this basal interval do not differentiate units belonging to the Precambrian basement from those exclusively linked to the evolution of the Paleozoic basin. In fact, the differentiation of diamictites of same provenance is not a easy task, because glacial processes occurs in continental scale and generally transpass the basin limits, resulting in the overlap of differents glaciogenic deposits, which causes misunderstanding of interpretation.

The inference of Neoproterozoic age for Cacoal Formation by Gaia et al. (2017), related to the Marinoan glacial event $(-635 \mathrm{Ma})$, basically indicates the ages of glacial levels in the studied region (Fig. 2). Following this new conception, it is important to verify which of the more ancient units of the Parecis Basin are exposed only in the PBG and Colorado Graben. More than $95 \%$ of the sedimentary deposits in this basin are post-Silurian. Pointedly, we conclude that the PBG and Colorado Graben are uplifted features with Precambrian basement rocks (crystalline rocks and Neoproterozoic cap carbonate) underlaid by Paleozoic siliciclastic deposits, in part glaciogene, that fill this depressions.

\section{FIELD PROCEDURES AND METHODS}

The stratigraphic framework proposed here is based on standard procedure for redescription and redefinition, according to Petri et al. (1986). The units show expressiveness, lithological uniformity, continuity and mappability along the northeastern edge of the PBG, where we concentrate the main stratigraphic sections. Facies analysis and stratigraphic correlation followed the concepts showed in Walker (1992). The sections carried out in open pit quarries and outcrops were sampled, measured, and examined in detail. The samples collected followed the facies separation, submitted afterwards to petrography and $\mathrm{x}$-ray diffraction analysis. The thin sections were stained by a mixed solution of alizarin red and potassium ferrocyanide, in order to distinguish between calcite and dolomite (Dickson 1966). The carbonate rocks nomenclature was based on the classification introduced by Dunham (1962).

\section{LITHOSTRATIGRAPHY AND DEPOSITIONAL SYSTEM}

The siliciclastic-carbonate succession in the studied area has an estimated thickness of up to 250 meters, obtained by stacking of stratigraphic sections, forming 
a composite section separated by two main stratigraphic surfaces or sequence boundaries (Fig. 3). In our proposal, the basement rocks include both crystalline and sedimentary rocks, considering which Neoproterozoic cap carbonate succession (diamictites and carbonates) represents a basement sedimentary cover redefined as the Cacoal Formation, composed of diamictites, and the Espigáo d'Oeste Formation, made up of carbonates (Fig. 4). The proposition of Espigão d'Oeste Formation is fully justified by its mappability and because it represents the dolomitic unit of a post-glacial cap carbonate (Nogueira et al. 2003, Allen \& Hoffman 2005, Gaia et al. 2017). Thus, as in other Precambrian sites worldwide, the cap carbonates are formally contextualized in lithostratigraphic units and, similarly, the basal contact is considered the limit between Late Cryogenian and Ediacaran periods (Kennedy 1996, Hoffman \& Schrag 2002, Nogueira et al. 2003, Xiao et al. 2016).

Based on stratigraphic relationships, we corroborate with Gaia et al. (2017), considering the Pimenta Bueno as exclusively Lower Paleozoic (Fig. 4). Table 1 shows a brief description and depositional settings of the sedimentary succession described in the PBG.

\section{Cacoal Formation}

\section{Description}

The Cacoal Formation unconformably overlies the basement rocks of the Amazonian Craton in the northeastern border of the PBG. The 10m-thick Cacoal Formation consists in lenticular to sub-horizontal beds of diamictites and sandstone (Figs. 3 and 4). The reddish to purplish clayey/silty matrix of massive diamictites exhibits poorly sorted clasts composed of angular to subrounded pebbles and cobbles (Figs. 5A and 5B). The clast composition include granite, gneiss, schist, volcanic rocks, rhyolite, sandstone, quartzite and other undifferentiated rock fragments. Faceted, polished and striated clasts are commonly found (Fig. 5C). The diamictite is overlaid by laminated siltstone and fine- to medium-grained sandstone with massive bedding or climbing ripple-cross lamination (Figs. 5D and 5E). Locally, isolated clasts disrupt and cut the underlying laminae.

\section{Interpretation}

The diamictites of the Cacoal Formation were previously interpreted by Bahia et al. (2006) as alluvial fans and, afterwards, considered as glacial deposits by Gaia et al. (2017). The glaciogene origin is corroborated here, considering the

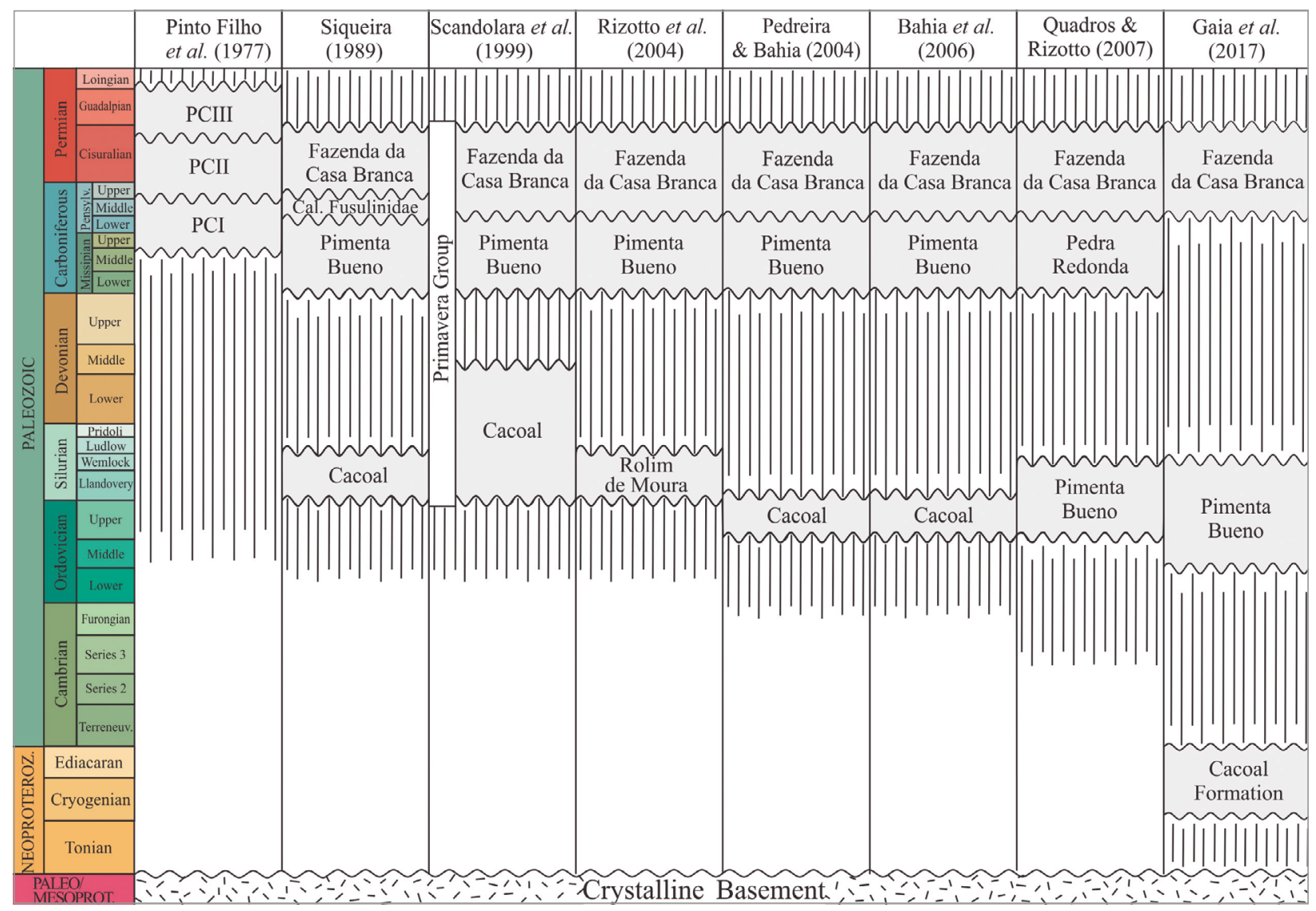

Figure 2. Chronostratigraphic proposals for the Pimenta Bueno Graben. 


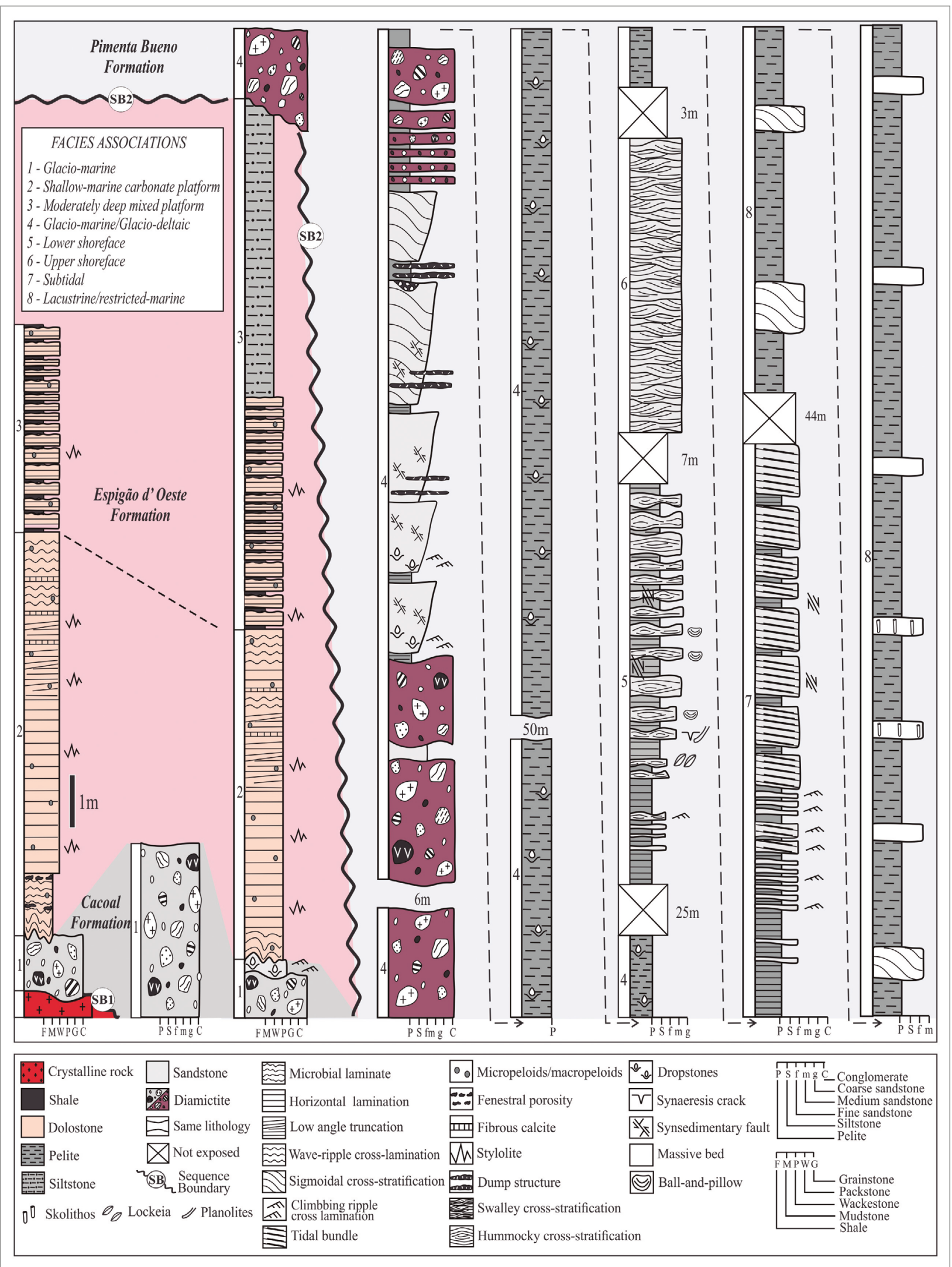

Figure 3. Stratigraphic sections of the Pimenta Bueno Graben. The composite section reach almost 250 meters thick. The SB1 represent the Marinoan post-glacial marine transgression surface and SB2 is interpreted as limit between Neoproterozoic (Ediacaran) and Paleozoic (Ordovician-Silurian) deposits. 


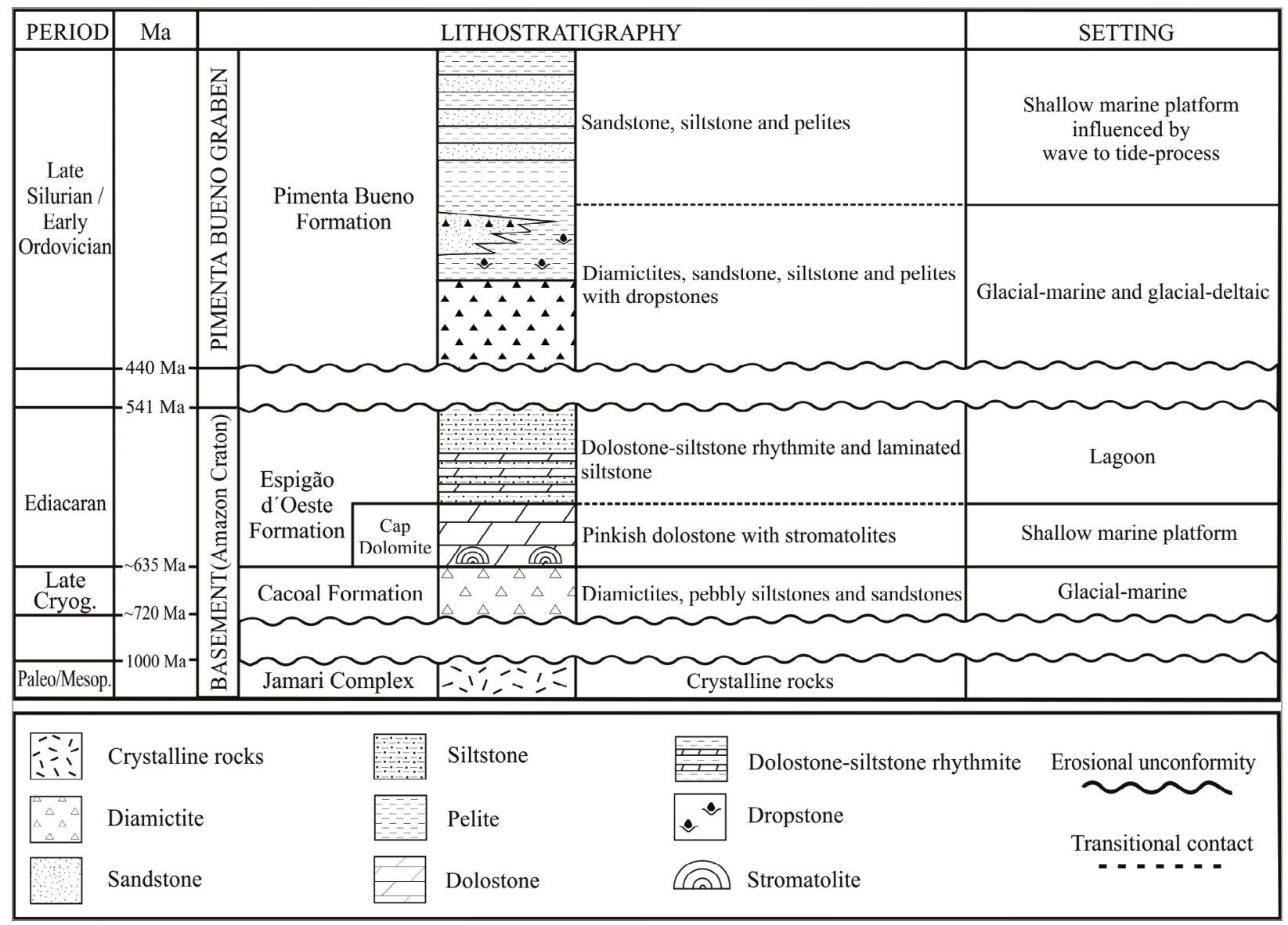

Figure 4. Lithostratigraphy of the Pimenta Bueno Graben, Southwesternmost Amazon Craton.

Table 1. Description and paleoenvironmental interpretation for units of the Pimenta Bueno Graben, Southwesternmost Amazon Craton.

\begin{tabular}{|c|c|c|c|}
\hline Period & Unit & Description & Depositional settings \\
\hline Cryogenian & $\begin{array}{c}\text { Cacoal } \\
\text { Formation }\end{array}$ & $\begin{array}{c}\text { Sheet-like to lenticular bodies (dm to m-scale) of matrix-supported } \\
\text { massive diamictite showing granules to boulders. Siltstone and } \\
\text { fine-medium grained sandstones with ripple cross lamination and } \\
\text { massive bedding occuring upsection. Dropstones are found locally in } \\
\text { the diamictite matrix. }\end{array}$ & Glacio-marine \\
\hline Ediacaran & $\begin{array}{l}\text { Espigão } \\
\text { d’Oeste } \\
\text { Formation }\end{array}$ & $\begin{array}{l}\text { Meters-thick tabular beds, composed of doloboundstone showing } \\
\text { irregular and milimetric microbial lamination, and pinkish } \\
\text { dolomudstone/dolopackstone with even parallel lamination, gently } \\
\text { undulated lamination and low-angle truncations. Microcrystalline peloids } \\
\text { are the major components, occurring isolated or in aggregates (clotted } \\
\text { texture). Dolostone/siltstone rhythmite and even parallel laminated } \\
\text { reddish siltstone predominate in the upper portion of this formation. }\end{array}$ & $\begin{array}{c}\text { Shallow-marine to } \\
\text { moderately deep mixed } \\
\text { platform }\end{array}$ \\
\hline $\begin{array}{l}\text { Late Silurian } \\
\text { to Early } \\
\text { Ordovician }\end{array}$ & $\begin{array}{l}\text { Pimenta } \\
\text { Bueno } \\
\text { Formation }\end{array}$ & $\begin{array}{l}\text { Lower Member: Metric layers composed of matrix-supported massive } \\
\text { diamictite with granular to boulder clasts interbedded with sigmoidal } \\
\text { cross-stratified sandstone and pelites displaying scattered clasts. } \\
\text { Upper Member: Tabular sandstone beds separated by mud drapes } \\
\text { with metric thickness, laterally continuous for dozens to thousand } \\
\text { meters. The well-sorted, fine-grained sandstone exhibit hummocky } \\
\text { and swaley cross stratification, even parallel stratification and low- } \\
\text { angle truncation interbedded with laminated pelite. Tidal rhythmite } \\
\text { and fine- to medium-grained sandstone with tabular/tangential cross } \\
\text { bedding and mud drapes in the foresets. Fine- to medium-grained } \\
\text { sandstone with concave to sigmoidal cross bedding and massive } \\
\text { bedding are locally bioturbated by Planolites, Lockeia and Skolithos }\end{array}$ & $\begin{array}{l}\text { Glacio-marine and } \\
\text { glacio-deltaic } \\
\text { Lower to upper } \\
\text { shoreface/ subtidal and } \\
\text { lacustrine-deltaic }\end{array}$ \\
\hline
\end{tabular}


immature sedimentary texture and the poorly sorted grains in diamictites, indicating the low capacity of glaciers to select sediments during transport. Faceted, polished and striated clasts indicate abrasion of the particles among themselves and with the substrate during transport (Eyles \& Eyles 1992). The clayey/silty matrix of the diamictite was formed by abrasive process during glacier displacement. In the final stages of Marinoan glaciation, the ice retreat provided the installation of platformal and coastal environments where sediments supplied by ice-melt waters were reworked by wave and weak currents. The presence of scattered clasts (dropstone) in siltstone and sandstone are interpreted as rain-out or icerafted debris (Brodzikowski \& Van Loon 1987, Brodzikowski \& Van Loon 1991, Eyles \& Eyles 1992, 2010).

\section{Espigão d'Oeste Formation}

\section{Description}

The Espigáo d'Oeste Formation consists of a 20 m-thick succession formed by tabular beds of dolostone and finegrained siliciclastics, laterally continuous for hundreds of meters (Fig. 3). The sedimentary bedding trends NW-SE $\left(\sim 120^{\circ} \mathrm{Az}\right)$, dipping gently $\left(3^{\circ}\right.$ up to $\left.15^{\circ}\right)$ towards SSW to the center of PBG. The facies/microfacies of this unit include microbial laminites (doloboundstone), peloidal dolomudstone/dolopackstone, dolostone/siltstone rhythmite and siltstone (Figs. 3 and 4).

A basal sharp contact that separates glaciogene sediments (Cacoal Formation) from the cap carbonate succession (Espigão d'Oeste Formation) is exposed in the northeastern border of the PBG. The contact zone is extremely irregular and, commonly, form metric-scale open folds with interlimb angle between $120^{\circ}$ to $70^{\circ}$, differentiating from small undulation of microbialites (Fig. 6A). Light-gray to pinkish-gray doloboundstone exhibits distinct to diffuse horizontal to irregularly-wavy microbial lamination developed immediately above the contact zone (Figs. 6A and 6B). This lamination is formed by irregular and crinkly micritic laminae dominantly composed of peloids, alternating with the thick layers of microspatic dolomite (Fig. 6C). Peloids display irregular shape, ranging from well-rounded to angular, generally poorly sorted and with sizes between 20 and $100 \mu \mathrm{m}$. Fenestral porosity, generally less than $1 \mathrm{~mm}$, occurs partly lined following the lamination, sometimes filled with microspar and spar calcite cement (Fig. 6C).

Thinly plane-parallel laminated dolomudstone/dolopackestone (Fig. 7A) overlies the doloboundstone. Locally, dolomudstone/dolopackestone exhibits even parallel to quasi-planar lamination, changing laterally to low-angle truncated lamination. Fibrous calcite is locally present, alternating with dolostone beds. The lamination consists of millimetric laminae of microcrystalline dolomite with well-preserved micropeloids, interbedded with thick laminae of macropeloids and micropeloids (Fig. 7B). The interpeloidal cement is characterized by xenotopic crystals of dolomite (Fig. 7B). Micropeloids range up to $0.05 \mathrm{~mm}$ in diameter, and are well-sorted and well-rounded, isolated and exhibit clotted (grumouse) texture. Macropeloids are common in dolomudstone/dolopackestone, with even parallel and low angle truncated lamination, generally forming discontinuous inverse-graded lenses (Fig. 7C). Macropeloids generally are spherical to subspherical, ranging from 2 to $5 \mathrm{~mm}$ in diameter, and are constituted of micropeloid clusters (Fig. 7D).

The upper portion of the Espigão d'Oeste Formation is characterized by dolomudstone/dolopackstone, alternating with fine siliciclastics forming rhythmites of usually less than 3 or $4 \mathrm{~mm}$ (Fig. 7E). Even parallel lamination is locally undulated, occasionally associated with ripple marks, representing the main structure of the succession. Thin laminations are composed by milimetric layers of microcrystalline and microspatic dolomite. Very fine silt to very fine sand-sized detrital terrigenous form the granulometry of rythmic lamination, and occur concentrated in dissolution seams (Fig. 7F). The terrigenous grains include quartz, potassium feldspar, plagioclase, chert, micas and clay minerals. Siliciclastic deposits gradually increase upsection, passing gradually to expressive beds of reddish siltstone showing even parallel lamination (Figs. 3 and 7G).

\section{Interpretation}

The fine laminated dolostone and siltstone of the Espigão d'Oeste Formation have been interpreted as deposits formed in shallow marine platform environment that gradually become moderately deeper (Gaia et al. 2017). The presence of thickly microbial laminite with peloids and fenestral porosity, suggest carbonate precipitation induced by microbial activity, probably sulfate, reducing bacteria in microbial mats (Riding 2000, James et al. 2001, Font et al. 2010, Pruss et al. 2010, Bosak et al. 2013, Romero et al. 2016). The recurrent laminae (biofilms) is the result of microbial activity, alternating with periods of low activity or biochemical inactivity (Pruss et al. 2010, Bosak et al. 2013). The irregular wavy macroscopic form of the microbial laminites implies initially a colonization of irregular substrate that, due the low energy of the environment, gradually develop stratiform laminae (Figs. 6A and 6B).

Waves action are indicated by dolomudstones/dolopackstones with even-parallel lamination, quasi-planar lamination, ripple marks and low angle truncated lamination. Macropeloids associated with low angle truncated lamination and ripple marks suggest and environment with relatively high-energy waters. Therefore, the preservation and 

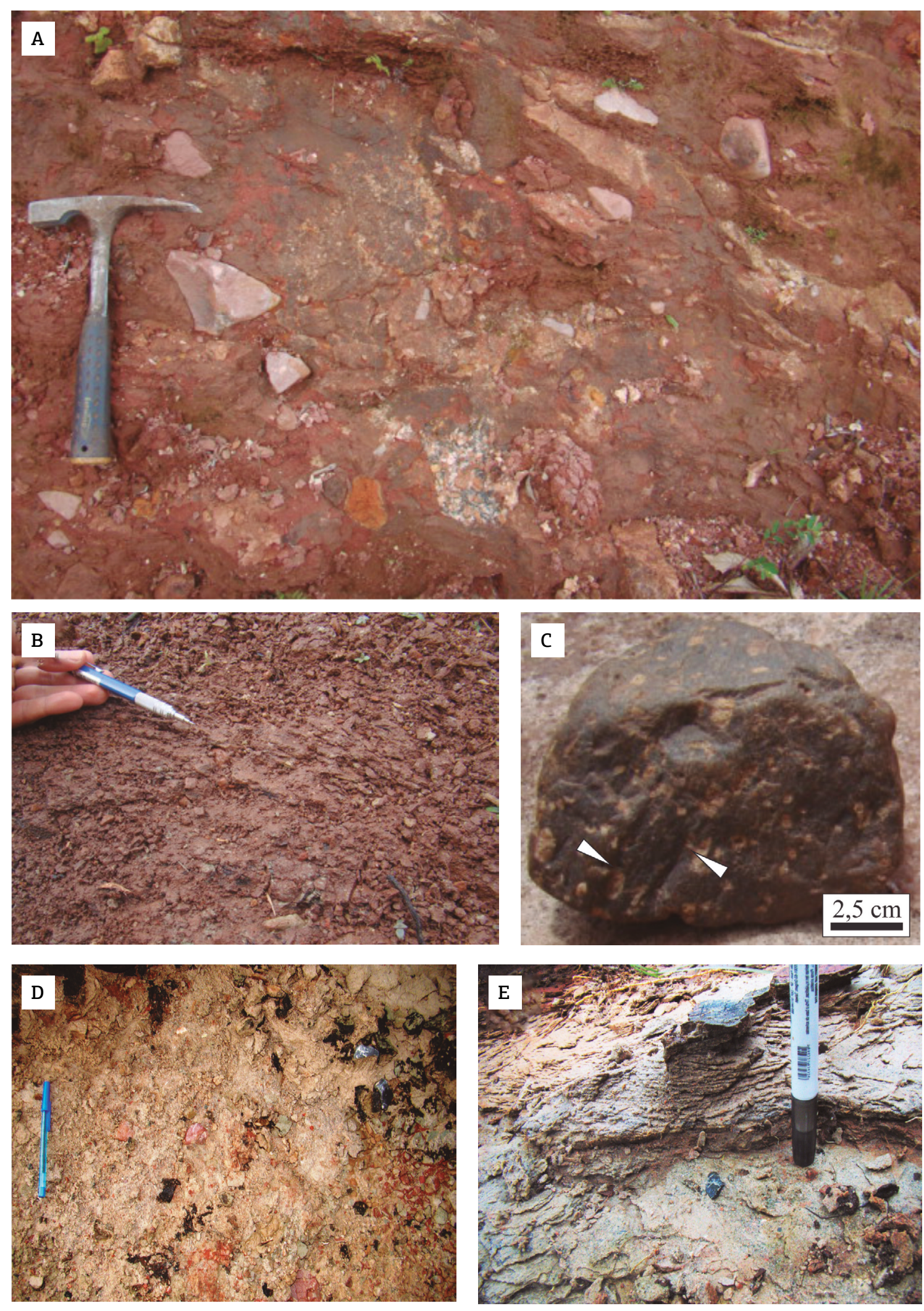

Figure 5. Deposits of the Cacoal Formation. (A) Massive (matrix-supported) diamictite showing blocks and faceted clasts. (B) Reddish to purplish clayey/silty matrix of diamictite. (C) Volcanic clast displaying grooves and striations (white arrows). (D) Massive sandstone with scattered clasts. (E) Fine-grained sandstone with climbing ripplecross lamination and isolated clasts. Pen in the photos $=15 \mathrm{~cm}$, hammer $=30 \mathrm{~cm}$. 

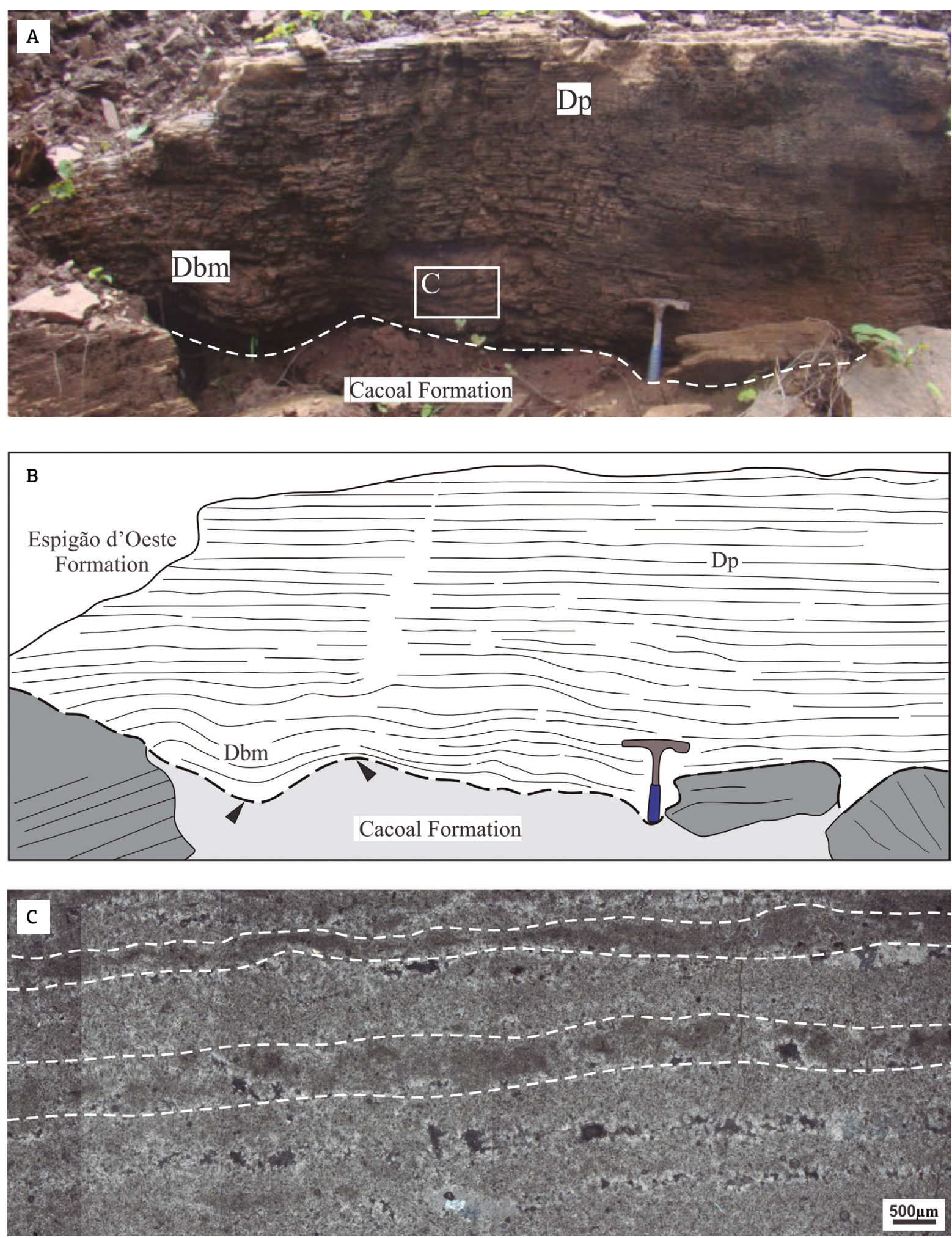

Figure 6. Contact zone between the Espigão d'Oeste and Cacoal formations. (A) Microbial lamination in doloboundstone on first centimeters of the Espigão d'Oeste Formation. (B) Schematic representation of (A). Note that microbial undulated laminae grade verticaly to stratiform stromatolite. (C) Photomicrography showing the alternation of microbial laminites texture marked by fenestras, peloidal dolomite and dolomicrospar. Abreviations, Dbm, microbial doloboundstone, Dp, peloidal doloboundstone. Hammer $=30 \mathrm{~cm}$. 

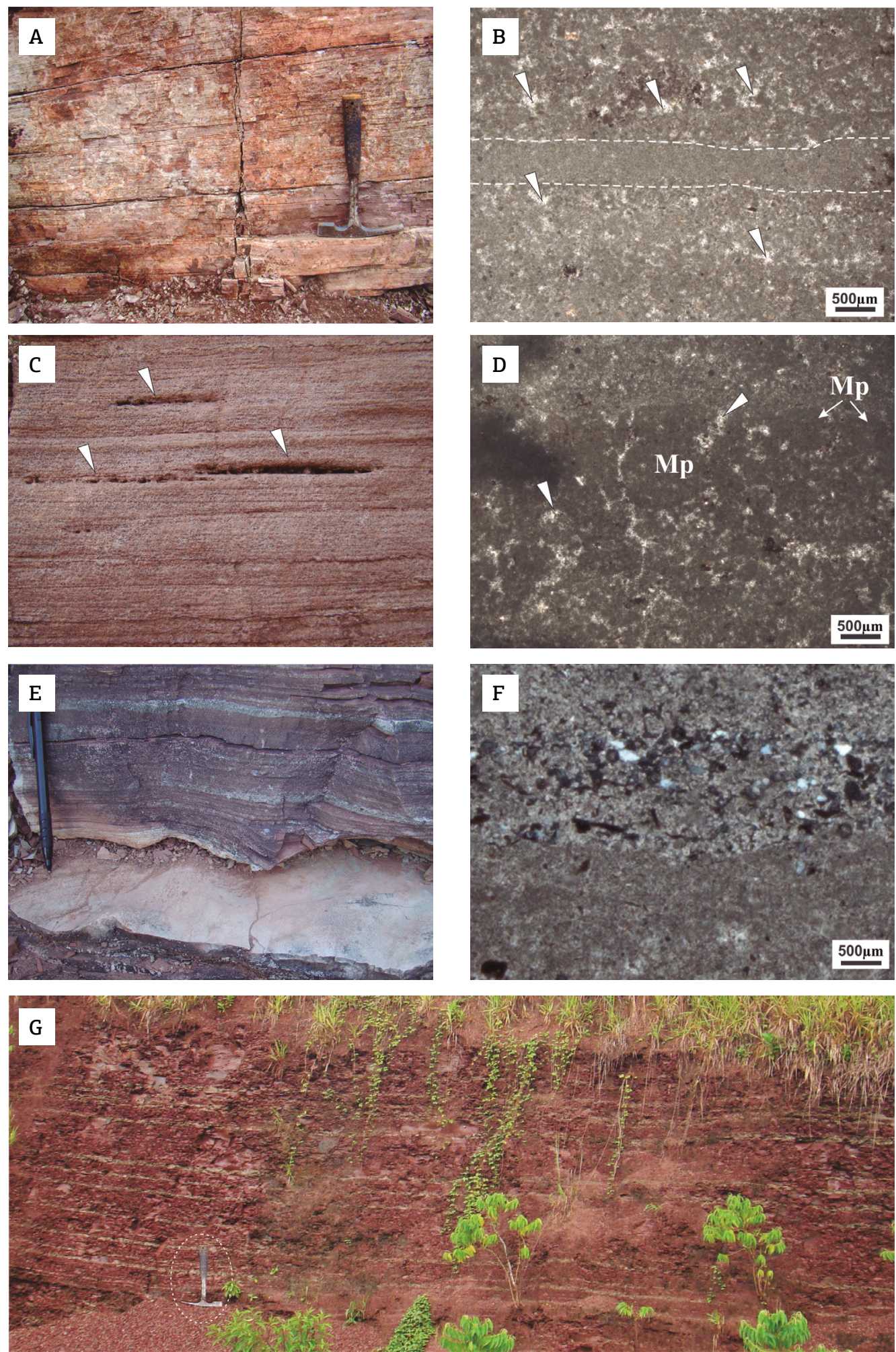

Figure 7. The upper portion of the Espigão d'Oeste Formation. (A) Even parallel laminated dolomudstone/ dolopackstone. (B) Peloidal dolopackstone with normally graded bedding; arrows indicate dolomite cement in interpeloidal porosity. (C) Dolumudstone/dolopackstone with quasi-planar and low angle truncated laminations marked by macropeloids lens (white arrows). (D) Macropeloids (Mp) and micropeloids cemented by dolomicrospar. (E) Dolomudstone/dolopackstone interbedded with siltstone forming rhythmite. (F) Siltstone laminae interbedded with dolomudstone in rhythmic facies, quartz grains are detached by light blue color. $(\mathrm{G})$ Metric layers of reddish siltstone with even parallel lamination. Pen in the photo $=15 \mathrm{~cm}$, hammer $=30 \mathrm{~cm}$. 
irregular distribution of macropeloid lens indicate deposition in situ, with little or no transport (James et al. 2001). In addition, the well-preserved peloids also indicate rapid cementation (Kennedy 1996, James et al. 2001).

The predominance of rhythmic deposition of dolomuds and fine siliciclastics in the upper portion of the Espigáo d'Oeste Formation indicated increased water depth, similarly to what was observed in others cap carbonate worldwide, such as in the Amazon Craton (Hoffman \& Schrag 2002, Nogueira et al. 2003). Additionally, the higher siliciclastic input probably contributed to the inhibition of carbonate precipitation in the moderately deep platformal environment (Williams et al. 2008, Gaia et al. 2017).

\section{Pimenta Bueno Formation}

\section{Description}

The Pimenta Bueno Formation consists essentially of siliciclastic rocks that unconformably overlies the Marinoan cap carbonate of the Espigão d'Oeste Formation (Figs. 3 and 4). The lower portion of this unit is characterized by diamictites interbedded with sandstones, siltistones and pelites. The diamictites are massive and display a fine-grained purplish to reddish matrix (silt and clay) with poorly sorted, subangular to angular clasts, ranging from millimeters to centimeters in diameter (Fig. 8A). The clasts composition includes granite, gneiss, schist, siltstone, basic volcanic rocks, and other undifferentiated litotypes (Fig. 8B). The clasts are commonly faceted and striated. The diamictite is recurrent in the succession and generally are interbedded with fine- to coarse-grained sandstone showing sigmoidal cross-stratification and massive bedding (Fig. 8C). Locally, metric-scale lens of massive sandstones are found interbedded with diamictites (Fig. 8D). Dump structures and synsedimentary subvertical faults occur at the base of sandy lobe (Fig. 8E). Even parallel laminated siltstone occurs in the lower portion of unit (Fig. 8F).

The upper portion of the Pimenta Bueno Formation is marked by the disappearance of diamictites and pelite with dropstone. Tabular beds and laterally continuous from dozens to hundred meters of sandstone, siltstone, rhythmite and pelitic rocks prevail. The reddish-brow fine- to medium-grained sandstones present well-sorted and rounded grains, displaying hummocky and swaley cross-bedding and, subordinately, ripple cross-lamination, low-angle and even parallel laminations (Fig. 9A). Moreover, there are sandstones with tabular/tangential cross stratification exhibiting mud drapes in the foresets (Figs. 9B and 9C). Symmetrical and asymmetrical ripple marks occur in fine-grained sandstone. The sandstone beds are individualized by centimetric layers of purplish laminated pelite. In the sandstone/pelite interface, flow structures and soft-deformation structures, such as sole marks and balls-and-pillows, are observed. Flute casts and synaeresis cracks are locally preserved. Sandstone/pelites rhythmite with flaser and wavy bedding ocurrs associated with cross-bedded sandstone (Fig. 9B). Near to the Cacoal city, pelitic beds interbedded with sigmoidal cross-stratificatified sandstones and massive sandstones (Fig. 9D) also occur. Bioturbation is rare, and trace fossils were observed locally, such as Planolites, Lockeia and Skolithos (Figs. 9E and 9F).

\section{Interpretation}

The Pimenta Bueno Formation was deposited in a complex environment, including glacial and post-glacial conditions, and a storm- and tide-dominated setting. The massive diamictites and pelitic beds with scattered clasts suggest the influence of glaciers covering an extense area in the Amazon Craton during the Ordovician-Silurian. Diamictons were produced by intense abrasion of glacier on basement rocks (Eyles et al. 1985, Powell 1990, Eyles 1993, Eyles \& Eyles 2010). The recurrence of phases of retreat and advance of ice generated different environments and explain the ciclicty observed in the Pimenta Bueno succession. During the advance phase the diamictons were the main sedimentation formed mainly on the base of glaciers as lodgement till (Eyles et al. 1985, Powell 1990, Eyles 1993, Eyles \& Eyles 2010). The ice cover retreat episodes were characterized by the increase of discharge of ice-melt waters, allowing the installation of stream flows and progradation of deltaic system. The melting icebergs or floating ice shelves released sediment incorporated by ice directly over deltaic and platformal deposits (Eyles \& Eyles 2010). Lens of pebbly sandstone found in the deltaic deposits of the Pimenta Bueno Formation suggest ice-rafted debris from icebergs during phases of ice-retreat.

After the main glacial episode, the post-glacial eustatic rise allowed the development of storm- and tidal-dominated environments. The presence of hummocky cross stratified sandstone and amalgamated layers swaley cross stratified sandstone suggest recurrence of storms in shallow marine environment (Harms et al. 1975, Dott \& Bourgeois 1983, Duke 1985, Dumas \& Arnott 2006, Vakarelov et al. 2012). Coastal environments were installed on the border of Amazon Craton, and the occurrence of storms suggests subtropical paleolatitude.

Deformational structures and synaeresis crack were induced by compactation and rapid sedimentation by a high amount of sedimentary overload of sandstone/pelite (Plummer \& Gostin 1981, Allen 1982, Pratt 1998). Tidal processes in the Pimenta Bueno Formation are characterized by intervals showing rhythmic bedding and tabular/tangential cross bedded sandstones with mud drapes in 

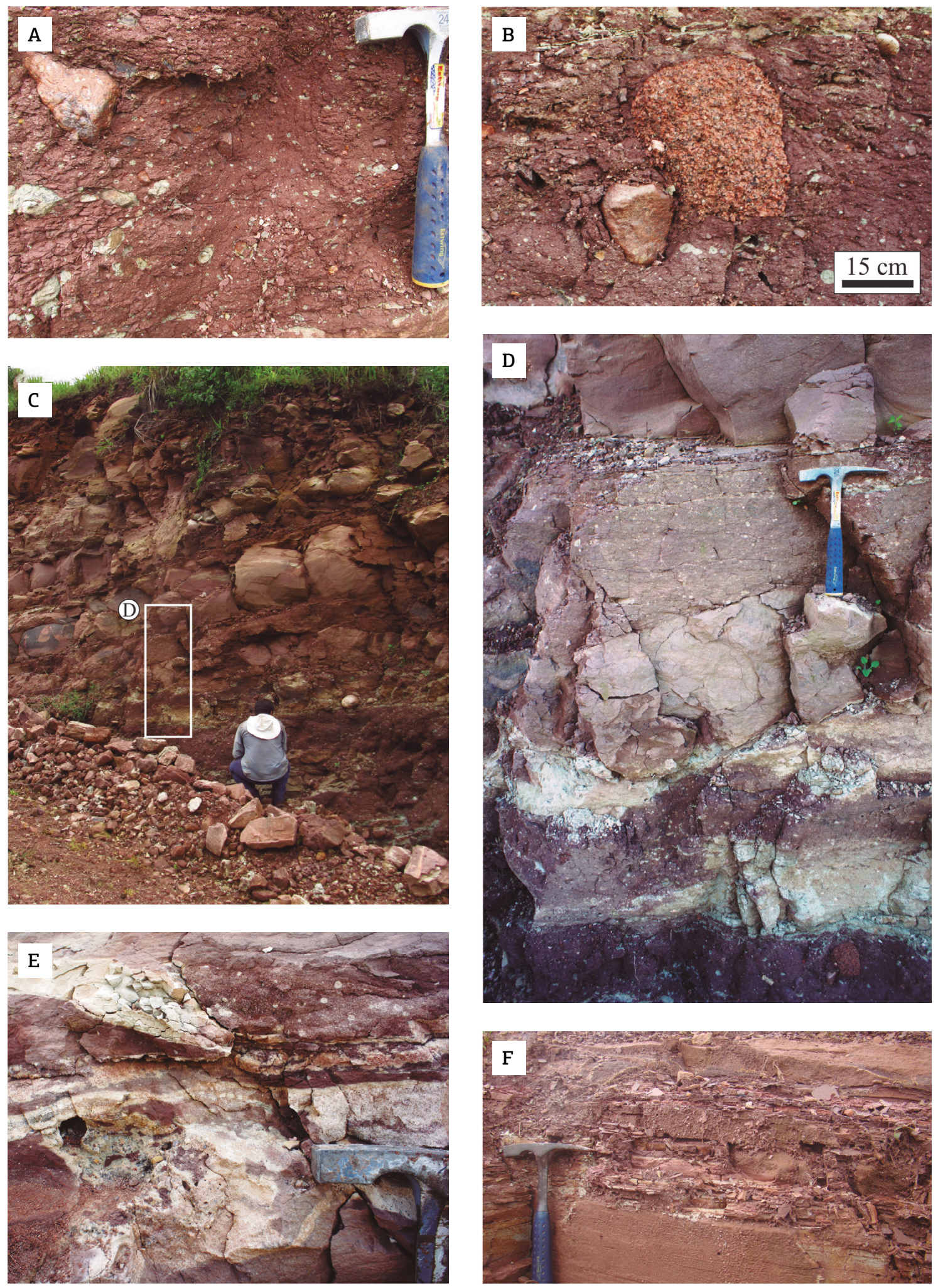

Figure 8. Faciologic aspect of the Lower Pimenta Bueno Formation. (A) Massive diamictites in the base of the Pimenta Bueno Formation. (B) Boulder-sized clats of granite. (C) Massive sandstone bodies overlying purplish diamictite. (D) Detail of (C) showing the alternance of coarse- to fine-grained sandstone with dimictite beds and lenses. (E) Pebbly sandstone in irregular lenses interpreted as dump structure. (F) Even parallel laminated siltstone. Hammer $=30 \mathrm{~cm}$. 

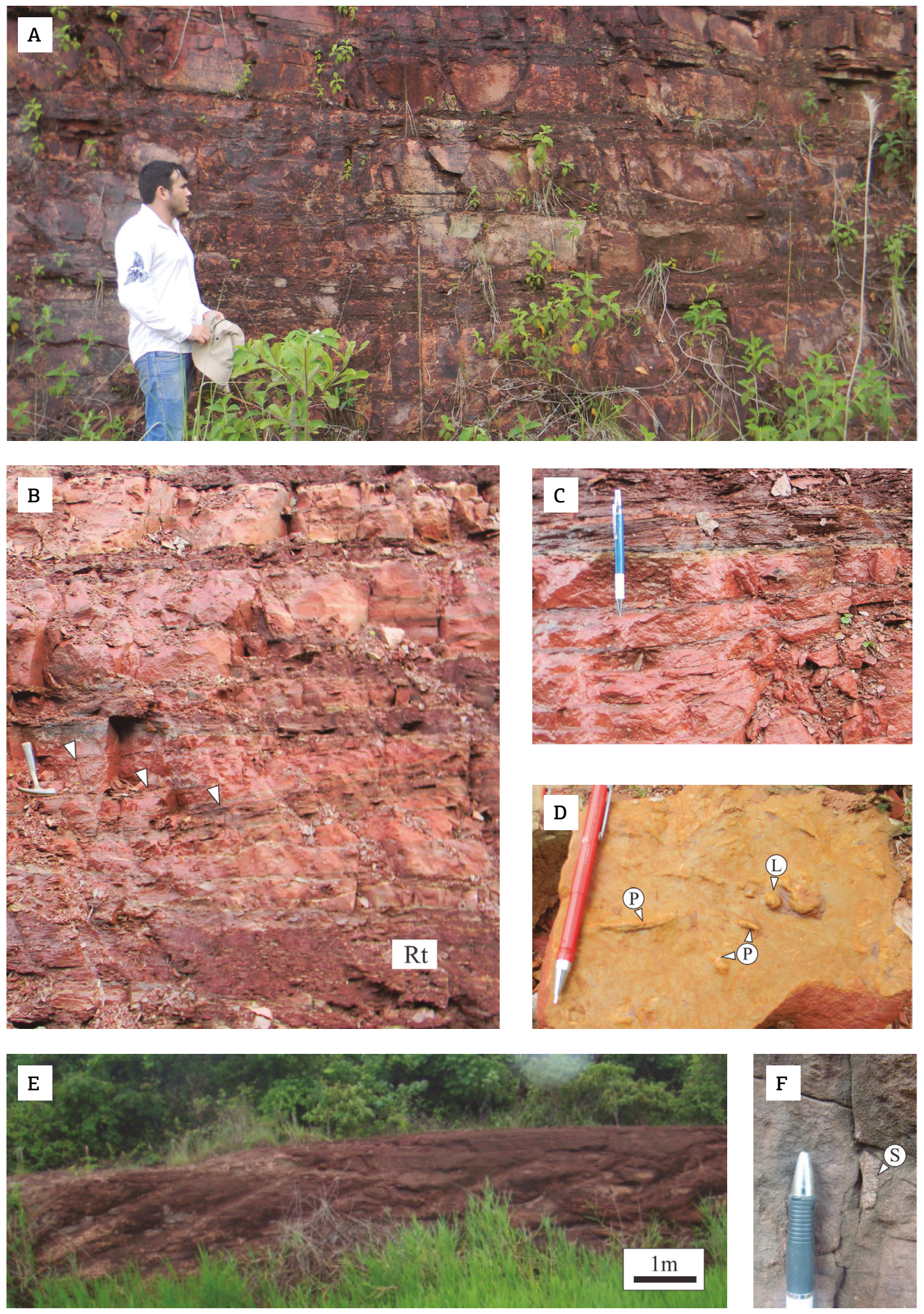

Figure 9. Upper portion of the Pimenta Bueno Formation. (A) Amalgamated hummocky cross-stratified fine sandstones and interbebbed laminated pelites. (B) Rhythmic alternance of very fine-grained sandstone and pelites, the top of sandstones are undulated and mud drapes separated the beds (arrows). (C) Detail of thin mud drape in the foresets and separating beds. (D) Sandstone exhibiting sigmoidal lobe geometry. (E) trace fossils of Planolites (P) and Lockeia (L). (F) Vertical burrows of Skolithos (S). Hammer $=30 \mathrm{~cm}$. Pen $=15 \mathrm{~cm}$. 
the foresets interpreted as tidal bundles, suggesting alternation of bed load and suspension load deposition linked to tidal cycles (Dalrymple \& Choi 2007, Dalrymple 2010, Longhitano et al. 2012). The presence of tidal processes in the upper portion of the Pimenta Bueno succession indicates connection to ocean and seas, most likely devoid of glaciation, representing an expressive interval of long term transgression.

The expressive beds, composed of pelites interbedded with amalgamated sigmoidal to complex cross-bedded sandstone, constitute the uppermost unit of the Pimenta Bueno Formation (Fig. 3). The rapid deceleration of terrigenous

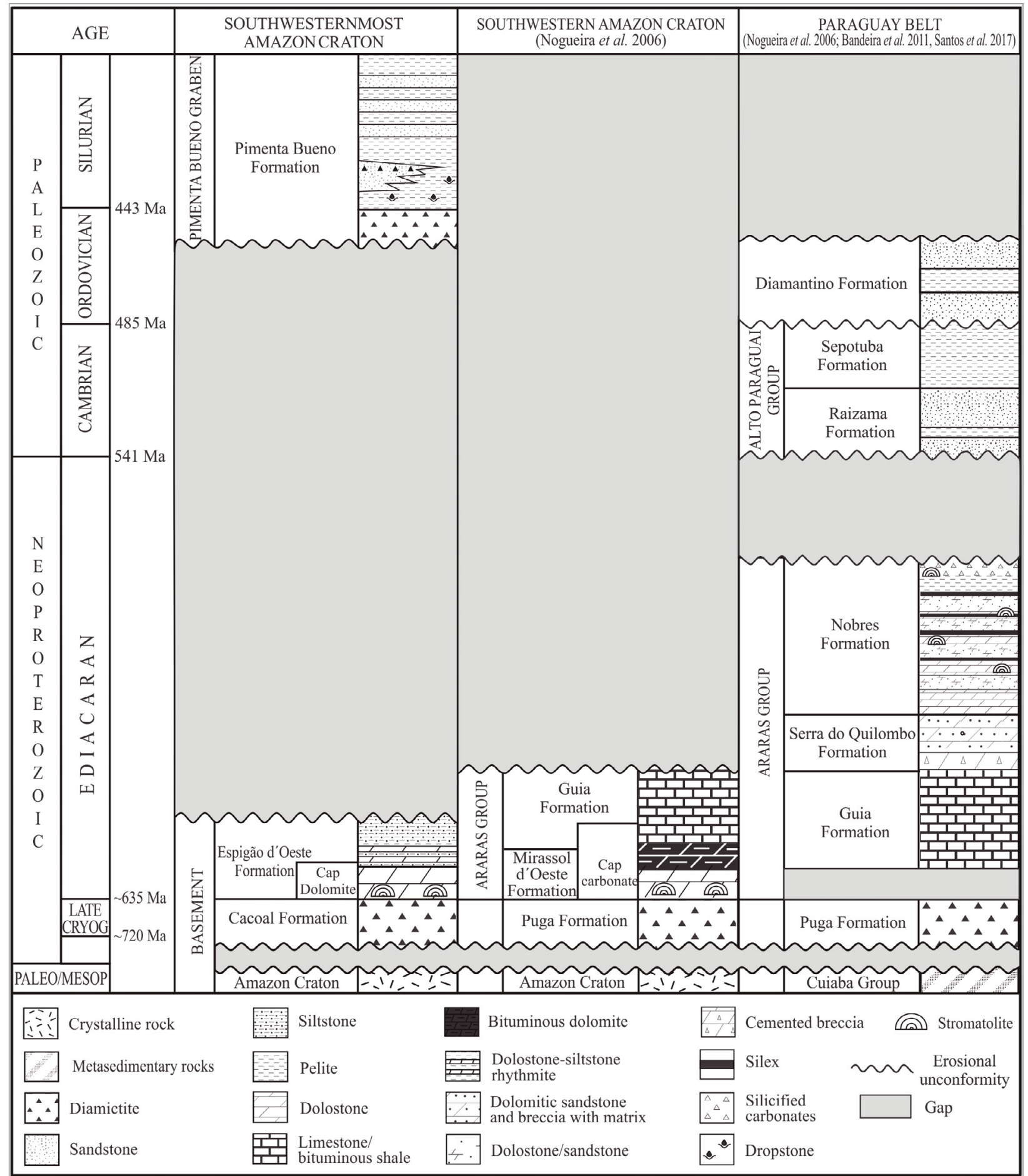

Figure 10. Stratigraphic units of the Southwesternmost Amazon Craton and its correlation with NeoproterozoicLower Paleozoic units of the Amazon Craton and Paraguay belt. 
influx forms the layers of lobate to massive sands. Fine sandstones with cross-lamination corroborate the occurrence of the tractive and suspension processes. This deposits have been interpreted as proximal mouth bars linked to the deltaic deposits. The delta progradation occurred in shallow waters lagoons, lake, or epicontinental ocean (cf. Postma 1990, Nichols 2009, Renaut \& Gierlowski-Kordesch 2010). The presence of Planolites, Lockeia and Skolithos attest high-energy environments and probably the fully marine character of the succession (Pemberton et al. 1992, Buatois \& Mángano 2009, Desjardins et al. 2010, MacEachern et al. 2010, Harazim et al. 2013, Santos et al. 2017).

\section{STRATIGRAPHIC CORRELATIONS}

The glaciogenic deposits underlying cap carbonates are widely distributed in Neoproterozoic successions but are most commonly associated with the Marinoan event (Corsetti \& Lorentz 2006, Fairchild \& Kennedy 2007, Li et al. 2013, Shields-Zhou et al. 2016). This event marked the end of the Cryogenian Period (ca. 720-635 Ma) and represents one of the most severe glaciations in Earth history (Hoffman et al. 1998, Fairchild \& Kennedy 2007, Prave et al. 2016). Cap dolostones were deposited in transgressive seas over formerly glaciated continental margins during Marinoan snowball deglaciation (Creveling \& Mitrovica 2014). It is formed by pink-colored, thinly-laminated dolostone that contains unusual sedimentary structures and commonly has negative $\delta^{13} \mathrm{C}$ values (<-5\%) (Kaufman \& Knoll 1995, Kaufman et al. 1997, Jiang et al. 2006, Sato et al. 2016). Large negative C-isotope excursions in the Neoproterozoic times are generally associated to the postglacial carbonate succession and probably reflect oceanographic processes (Kaufman et al. 1991, Kaufman et al. 1997, Hoffman et al. 1998). In Brazil, several studies conducted in the southwestern Amazonian Craton recognized diamictite underlying post-glacial carbonate Neoproterozoic successions (Nogueira \& Riccomini 2006, Alvarenga et al. 2008, Soares \& Nogueira 2008, Soares et al. 2013).

The Espigão d'Oeste cap dolostones, which overlay the glacial diamictites of the Cacoal Formation exposed on the edge of the PBG, were compared to other post-Marinoan cap carbonates using sedimentary facies, stratigraphic relationship and carbon isotope porfiles (cf. Gaia et al. 2017). The carbonate succession herein described have similarities to other coeval cap carbonates, such as: pink color, finely lamination, crystalline dolostone, presence of microbial laminates and tipically peloidal fabric composed of micro and macropeloids. In addition, the $\delta^{13} \mathrm{C}$ of the Espigão d'Oeste cap dolostones exhibits typically negative values around -4 \%o and -2 \%o (Dardenne et al. 2005, Afonso 2016, Gaia et al. 2017). These values are comparable with $\delta^{13} \mathrm{C}$ profiles of post-late Cryogenian units of Southern Paraguay Belt (Nogueira et al. 2007, Alvarenga et al. 2008, Sial et al. 2016) and other cap carbonates formed after Marinoan glaciation (Kennedy 1996, James et al. 2001, Hoffman \& Schrag 2002, Halverson et al. 2010).

The age of the Pimenta Bueno Formation is still uncertain. Pinto Filho et al. (1977) based on pollen assemblage affiliated to vegetal groups of the Pterophyta and Lycopodophyta, attributed Permo-Carboniferous Age to this unit. Cruz (1980) described the acritarch Synsphaeridium sp., in black shales exposed near Cacoal city, suggesting a Siluro-Devonian age. According to Bahia (2007) this fossil represents an evidence for Permo-Carboniferous Age, while for Goldberg et al. (2011) the acritarch genus can inequivocally suggest ages near to the Silurian-Devonian limit. However, the Synsphaeridium $s p$. is described since Neoproterozoic age deposits, providing a large age interval and compromising the use of this genus as inference of age (Vidal et al. 1994, Stanevick et al. 2005, Teyssèdre 2006). The stratigraphic relationship described here revealed the existence of an angular unconformity at the base of the Pimenta Bueno Formation with the Espigão d'Oeste Formation. In this study, we suggest the Silurian age to the Pimenta Bueno Formation, conferring especially the Llandovery Epoch, compatible with the first glacial episodes in intracratonic basins such as the Amazon, Paraná and Parnaíba basins (Caputo 1984, Assine 1996, Assine et al. 1998, Díaz-Martínez \& Grahn 2007, Cuervo 2014).

The stratigraphy of sedimentary deposits exposed in the Southwesternmost Amazon Craton is redefined, and its correlation with adjacent regions is shown in Figure 10. This new proposal, modifying the current Early Paleozoic stratigraphy for the Parecis Basin, indicates, at least, two levels of glaciation exposed in the Sothwesternmost Amazon Craton related to the Marinoan and Late Ordovician-Early Silurian events. Additionally, the new stratigraphic proposal better organizes the depositional events of the Pimenta Bueno sedimentation, indicating an expressive long term (post-glacial) transgression that can be used as an important stratigraphic marker with the other Paleozoic basins.

\section{CONCLUSIONS}

The integration of results obtained by stratigraphic studies in the Southwesternmost Amazon Craton provided a new stratigraphic framework for the PGB, sub-basin of the Parecis Basin. According to our new proposal, the sedimentary record was subdivided into three units. The Cacoal formation is the basal unit, consisting of diamictites, sandstone/ 
siltstone with dropstone. The Espigão d'Oeste Formation is made up stromatolites, pinkish dolostone, dolostone-siltstone rhythmite and siltstone. The lowermost Espigão d'Oeste is the cap carbonate deposited during post-glacial transgression related to the Marinoan event $(-635 \mathrm{Ma})$. The glacial diamictite-cap carbonate couplet, once considered paleozoic is herein considered part of the basement cover of the PBG, without relation to the Paleozoic succession of the Parecis Basin.

The Pimenta Bueno Formation unconformably overlies the Precambrian basement rocks - crystalline and sedimentary- and consist of diamictites, sandstones, siltstones and pelites, which contain widely scattered small clasts. The Pimenta Bueno Formation is positioned on the OrdovicianSilurian interval and registers a glacial event synchronous with other intracratonic basins of South America, such as Amazon, Paraná and Parnaíba basins. Post-glacial transgression promotes sea level rise with development of storm-tidal influenced shallow platform. The presence of Planolites, Lockeia and Skolithos corroborates the marine influence.

Finally, this new stratigraphic proposal modifies the current Early Paleozoic stratigraphy for the Parecis Basin indicating the Marinoan and Late Ordovician-Early Silurian glacial events. The record of the last Cryogenian glaciation in the State of Rondônia expands the Snowball Earth conditions to the Southwesternmost Amazon Craton. This study provides new stratigraphic guide to future research in the PGB, as well as to contribute to the understanding of the late Precambrian-Early Paleozoic boundary and sedimentary history of this part of Amazônia.

\section{ACKNOWLEDGEMENTS}

We would like to thank financial support from CAPES (Coordenação de Aperfeiçoamento de Pessoal de Nivel Superior) for granting a Masters Scholarship to the first author, and to the Instituto Nacional de Ciência e Tecnologia de Geociências na Amazônia (INCT/GEOCIAM) (INCT/CNPq/MCT/ FAPESPA program, Grant no. 573733/2008-2) for the financial support during field work. This research was also supported by the CNPq (Grant no. 304423/2012-2) Research Productivity Fellowship Program. Thanks are expressed to UFPA (Universidade Federal do Pará), especially to PPGG (Programa de Pós-Graduaçáo em Geologia e Geoquímica) for the infrastructure. To Ruy Bahia and Marcos Quadros of Geological Survey (CPRM), for the important information provided about the geology of Rondonia. The authors would also like to thank the Rondonia Mining Company (RMC), as well as the anonymous reviewers for correction and discussion, and editor Claudio Riccommini for his valuable comments and suggestions.

\section{REFERENCES}

Afonso J.W.L. 2016. A transição Neoproterozoico-Eopaleozoico no Graben Pimenta Bueno, NW da Bacia dos Parecis, Estado de Rondônia. MS Dissertation, Universidade Federal do Pará, Belém, 100 p.

Allen J.R.L. 1982. Sedimentary structures, their character and physical basis. Developments in Sedimentology, 30A and B, Vol. I, 593 p., Vol II, 663 p. Elsevier, Amsterdam.

Allen P.A. \& Hoffman P.F. 2005. Extreme winds and waves in the aftermath of a Neoproterozoic glaciation. Nature, 433:123-127.

Almeida F.F.M. 1983. Relações tectônicas das rochas alcalinas mesozóicas da região meridional da Plataforma Sul-Americana. Revista Brasileira de Geociências, 13(3):139-158.

Alvarenga C.J.S., Dardenne M.A., Santos R.V., Brod E.R., Gioia S.M.C.L., Sial A.N., Dantas E.L., Ferreira V.P. 2008. Isotope stratigraphy of Neoproterozoic cap carbonates in the Araras Group, Brazil. Gondwana Research, 13(4):469-479.

Assine M.L. 1996. Aspectos da Estratigrafia das Sequencias PréCarboníferas da Bacia do Paraná. Programa de Pós-Graduação em Geologia Sedimentar. PhD Thesis, Universidade de São Paulo, São Paulo, 220 p.

Assine M.L., Alvarenga C.J.S., Perinotto J.A.J. 1998. Formação Iapó: Glaciação Continental no Limite Ordoviciano/Siluriano da Bacia do Paraná. Revista Brasileira de Geociências, 28(1):51-60.
Bahia R.B.C \& Pedreira A.J. 1996. Depósitos glaciogênicos da Formação Pimenta Bueno (Carbonífero) na região de Rolim de Moura, sudeste de Rondônia. A Terra em Revista, 1:24-29.

Bahia R.C., Quadros M.L., Pedreira A.J. 1996. As coberturas sedimentares fanerozóicas da região sudeste de Rondônia. In: SBG, Congresso Brasileiro de Geologia, Salvador, Anais, p. 293-302.

Bahia R.C., Martins-Neto M.A, Barbosa M.S.C., Pedreira A.J. 2006. Revisão estratigráfica da Bacia dos Parecis - Amazônia. Revista Brasileira de Geociências, 36(4):692-703.

Bahia R.C. 2007. Evolução tectonossedimentar da Bacia dos Parecis Amazônia. PhD Thesis, Universidade Federal de Ouro Preto, Minas Gerais, 121 p.

Buatois L.A \& Mángano M.G. 2009. Applications of ichnology in lacustrine sequence stratigraphy: Potencial and limitations. Palaeogeography, Palaeoclimatology, Palaeoecology, 272(3-4):127-142.

Bosak T., Mariotti G., Perron J.T., MacDonald F.A., Pruss S.B. 2013. Microbial sedimentology of stromatolites in the Neoproterozoic cap carbonates. In: Bush A. M. et al. (eds) Ecosystems Paleobiology and Geobiology. Paleontological Special Papers, The Paleontological Society, Boulder, CO, USA, 19:51-75. 
Brodzikowski K. \& Van Loon A.J. 1987. A systematic classification of glacial and periglacial environments, facies and deposits. EarthScience Reviews, 24(5):297-381.

Brodzikowski K. \& Van Loon A.J. 1991. Glacigenic sediments. Developments in Sedimentogy, 49. Amsterdam, Elsevier. 674 p.

Caputo M.V. 1984. Stratigraphy, tectonics, paleoclimatology and paleography of the northern basins of Brazil. PhD Thesis, University of California, $533 \mathrm{p}$.

Corsetti F.A \& Lorentz N.J. 2006. On Neoproterozoic cap carbonates as chronostratigraphic markers. In: Xiao S. \& Kaufman A.J. (eds.). Neoproterozoic Geobiology and Paleobiology, 273-294.

Creveling J.R \& Mitrovica J.X. 2014. The sea-level fingerprint of a Snowball Earth deglaciation. Earth and Planetary Science Letters, 399:74-85.

Cruz N.M.C. 1980. Palinologia de sedimentos paleozóicos do Território Federal de Rondônia. In: SBG, Congresso Brasileiro de Geologia, 31, Anais. p. 3041-3048.

Cuervo H.D.R. 2014. Fácies sedimentares das unidades Silurodevonianas aflorantes na porção sudeste do município de Presidente Figueiredo, borda norte da Bacia do Amazonas - AM. DM Dissertation, Universidade Federal do Amazonas, Manaus, 105 p.

Dardenne M.A., Alvarenga C.J.S., Oliveira C.G., Lenharo S.L.R. 2005. Geologia e metalogenia do depósito de Cobre do Graben do Colorado, Fossa Tectônica de Rondônia, Brasil. In: Marini O.J., Queiroz E.T., Ramos B.W. (Coords.). Caracterização de Depósitos Minerais em Distritos Mineiros da Amazônia. Brasília: DNPM - CT-Mineral/FINEP - ADIMB, 557-596.

Dalrymple R.W. \& Choi K. 2007. Morphologic and facies trends through the fluvial-marine transition in tide-dominated depositional systems: A schematic framework for environmental and sequence-stratigraphic interpretation. Earth-Science Reviews, 81(3-4):135-174

Dalrymple R.W. 2010. Tidal depositional systems. In: James N.P. \& Dalrymple R.W. (Eds.), Facies Models, 4, GEOText6, Geol. Assoc., Canada, pp. 199-208

Desjardins P.R., Mángano M.G., Buatois L.A., Pratt B.R. 2010. Skolithos pipe rock and associated ichnofabrics from the southern Rocky Mountains, Canada: Colonization trends and environmental controls in an early Cambrian sand-sheet complex. Lethaia, 43(4):507-528.

Díaz-Martínez E. \& Grahn Y. 2007. Early Silurian glaciation along the western margin of Gondwana (Peru, Bolivia and northern Argentina): Palaeogeographic and geodynamic setting. Palaeogeography, Palaeoclimatology, Palaeoecology, 245(1-2):62-81.

Dickson J.A.D. 1966. Carbonate identification and genesis as revealed by staining. Journal Sedimentary Petrology, 36(2):491-505

Dott R.H. \& Bourgeois J. 1983. Hummocky stratification: Significance of its variable bedding sequences: Discussion and reply. Geological Society Of America Bulletin, 94(10):1249-1251.

Duke W.L. 1985. Hummocky cross-stratification, tropical hurricanes, and intense winter storms. Sedimentology, 32(2):167-194.

Dumas S. \& Arnott R.W.C. 2006. Origin of hummocky and swaley cross-stratification - The controlling influence of unidirectional current strength and aggradation rate. Geology, 34(12):1073-1076.

Dunham R.J. 1962. Classification of Carbonate Rocks According to Depositional Texture. In: Ham W.E. (Ed). Classification of Carbonate Rocks. AAPG, Tulsa, 108-121.

Eyles C.H., Eyles N., Miall A.D. 1985. Models of glaciomarine sedimentation and their application to the interpretation of ancient glacial sequences. Palaeogeography, Palaeoclimatolology, Palaeoecology, 51(1-4):15-84.
Eyles N. \& Eyles C.H. 1992. Glacial depositional systems. In: Walker, R.G., James, N.P. (Eds.), Facies Models: Response to Sea Level Change. Geological Association of Canada Special Publication, St. Johns, NF, p. 73-100.

Eyles N. 1993. Earth's glacial record and its tectonic setting. EarthScience Reviews, 35(1-2):1-248.

Eyles C.H. \& Eyles N. 2010. Glacial deposits, In: James N.P. \& Dalrymple R.W. eds. Facies Models 4. Geological Association of Canada, GEOtext 6, 73-104.

Fairchild I.J. \& Kennedy M.J. 2007. Neoproterozoic glaciation in the

Earth System. Journal of the Geological Society, 164(5):895-921.

Font E., Nédélec A., Trindade R.I.F., Moreau C. 2010. Fast or slow melting of the Marinoan Snowball Earth? The cap dolostone record. Palaeogeography, Palaeoclimatology, Palaeoecology, 295(1-2):215-225.

Gaia V.C.S., Nogueira A.C.R., Domingos F.H.G., Sans-Jofre P., Bandeira Júnior J.C.S., Oliveira J.G.F., Sial A.N. 2017. The new occurrence of Marinoan cap carbonate in Brazil: The expansion of snowball Earth events to the southwesternmost Amazon Craton. Journal of South American Earth Sciences, 76:446-459

Goldberg K., Morad S., Al-Aasm I.S., De Ros L.F. 2011. Diagenesis of Paleozoic playa-lake and ephemeral-stream deposits from the Pimenta Bueno Formation, Siluro-Devonian (?) of the Parecis Basin, central Brazil. Journal of South American Earth Sciences, 32(1):58-74.

Halverson G.P., WadeB.P.,Hurtgen M.T., Barovich K.M.2010.Neoproterozoic chemostratigraphy. Precambrian Research, 182(4):337-350.

Harazim D., Callow R.H.T., Mcilroy D. 2013. Microbial mats implicated in the generation of intrastratal shrinkage ('synaeresis') cracks. Sedimentology, 60(7):1621-1638.

Harms J.C., Southard J.B., Spearing D.R., Walker R.G. 1975. Depositional environments as interpreted from primary sedimentary structures and stratification sequences: Society for Sedimentary Geology (SEPM) Short Course 2, $161 \mathrm{p}$.

Hoffman P.F., Kaufman A.J., Halverson G.P., Schrag D.P. 1998. A Neoproterozoic Snowball Earth. Science, 281(5381):1342-1346.

Hoffman P.F. \& Schrag D.P. 2002. The Snowball Earth hypothesis: Testing the limits of global changes. Terra Nova, 14(3):129-155.

James N.P., Narbonne G.M., Kyser T.K. 2001. Late Neoproterozoic cap carbonates: Mackenzie Mountains, northwestern Canada: Precipitation and global glacial meltdown. Canadian Journal of Earth Sciences, 38(8):1229-1262

Jiang G., Kennedy M.J., Christie-Blick N., Wu H., Zhang S. 2006. Stratigraphy, sedimentary structures, and textures of the late Neoproterozoic Doushantuo Cap Carbonate in South China. Journal of Sedimentary Research, 76(7):978-995.

Kaufman A.J., Hayes J.M., Knoll A.H., Germs G.J. 1991. Isotopic compositions of carbonates and organic carbon from upper Proterozoic successions in Namibia: Stratigraphic variation and the effects of diagenesis and metamorphism. Precambrian Research, 49:301-327.

Kaufman A.J. \& Knoll A.H. 1995. Neoproterozoic variations in the C-isotopic composition of seawater: Stratigraphic and biogeochemical implications. Precambrian Research 73: 27-49.

Kaufman A.J., Knoll A.H., Narbonne G.M. 1997. Isotopes, ice ages and terminal Proterozoic earth history. Proceedings of the National Academy of Sciences of the United States of America, 94(13):6600-6605

Kennedy M.J. 1996. Stratigraphy, sedimentology, and isotopic geochemistry of Australian Neoproterozoic postglacial cap dolostones: Deglaciation, $\mathbf{8 1 3 \mathrm { C }}$ excursions, and carbonate precipitation. Journal of Sedimentary Research, 66:1050-1064. 
Li Z.X., Evans D.A.D., Halverson G.P. 2013. Neoproterozoic glaciations in a revised global palaeogeography from the breakup of Rodinia to the assembly of Gondwanaland. Sedimentary Geology, 294:219-232.

Longhitano S.G., Mellere D., Steel R.J., Ainsworth R.B. 2012. Tidal depositional systems in the rock record: A review and new insights. Sedimentary Geology 279:2-22.

MacEachern J.A., Pemberton S.G., Gingras M.K., Bann K.L. 2010. Ichnology and facies models. In: James N.P. \& Dalrymple R.W. (eds.). Facies Models 4. Geological Association of Canada. GEOtext. p. 19-58.

Nichols G. 2009. Sedimentology and Stratigraphy. Second Edition. Wiley-Blackwell. 432p.

Nogueira A.C.R., Riccomini C., Sial A.N., Moura C.A.V., Fairchild T.R. 2003. Soft-sediment deformation at the base of the Neoproterozoic Puga cap carbonate (southwestern Amazon craton, Brazil): Confirmation of rapid icehouse to greenhouse transition in snowball Earth. Geology, 31(7):613-616.

Nogueira A.C.R. \& Riccomini C. 2006. O Grupo Araras (Neoproterozóico) na parte norte da Faixa Paraguai e sul do Cráton Amazônico, Brasil. Revista Brasileira de Geociências, 36(4):623-640.

Nogueira A.C.R., Riccomini. C, Sial A.N., Moura C.A.V., Trindade R.I.F., Fiarchild T.R. 2007. Carbon and strontium isotope fluctuations and paleoceanographic changes in the late Neoproterozoic Araras carbonate platform, southern Amazon craton, Brazil. Chemical Geology, 237(1-2):168-190.

Pedreira A.J \& Bahia R.B.C. 2000. Sedimentary Basins of Rondônia State, Brazil: Response to the geotectonic evolution of the Amazonic Craton. Revista Brasileira de Geociências, 30(3):477-480.

Pedreira A.J. \& Bahia R.B.C. 2004. Estratigrafia e Evolução da Bacia dos Parecis Região Amazônica, Brasil: integração e síntese de dados dos Projetos Alto Guaporé, Serra Azul, Serra do Roncador, CentroOeste de Mato Grosso e Sudeste de Rondônia. Brasília: CPRM. Serviço Geológico do Brasil/DEPAT/DIEDIG, 39p.

Pemberton S.G., MacEachern J.A., Frey R.W. 1992. Trace fossil facies models: Environmental and allostratigraphic significance. In: Walker R.G. \& James N.P. (eds.). Facies Models: Response to sea level change. Geological Association of Canada. p. 47-72.

Petri S., Coimbra A.M., Amaral G., Ojeda y Ojeda H., Fúlfaro V.J., Ponçano W.L. 1986. Código Brasileiro de Nomenclatura Estratigráfica. Revista Brasileira de Geociências, 16:372-415.

Pinto Filho F.P., Freitas A. F., Melo C. F., Romanini S.J. 1977. Projeto Sudeste de Rondônia. DNPM/CPRM, Porto Velho, Relatório final, 4 v.

Plummer P.S. \& Gostin V.A. 1981. Shrinkage cracks: Desiccation or synaeresis. Journal of Sedimentary Petrology, 51(4):1147-1156.

Postma G. 1990. Depositional architecture and facies of river and fandeltas: a synthesis. In: Colella, A., Prior, D.B. (Eds.), Coarse-grained Deltas, International Association of Sedimentologists, Special Publication, vol. 10, pp. 13 - 27.

Powell R.D. 1990. Glacimarine processes at grounding-line fans and their growth to ice-contact deltas. In: Dowdeswell J.A. \& Scourse J.D. (eds.) Glacimarine Environments: Processes and Sediments. London, Geological Society (Special Paper 53), 53-73.

Pratt B.R. 1998. Syneresis cracks: Subaqueous shrinkage in argillaceous sediments caused by earthquake-induced dewatering. Sedimentary Geology, 117(1-2):1-10.

Prave A.R., Condon D.J., Hoffmann K.H., Tapster S., Fallick A.E. 2016. Duration and nature of the end-Cryogenian (Marinoan) glaciation. Geology, 44(8):631-634.

Pruss S.B., Bosak T., Macdonald F.A., McLane M., Hoffman P.F. 2010. Microbial facies in a Sturtian cap carbonate, the Rasthof
Formation, Otavi Group, northern Namibia. Precambrian Research, 181(1-4):187-198.

Quadros M.L.E.S. \& Rizzotto G.J. 2007. Geologia e recursos minerais do Estado de Rondônia: texto explicativo do mapa geológico e de recursos minerais do Estado de Rondônia-escala 1:1.000.000. Porto Velho: CPRM, 116 p.

Renaut R.W. \& Gierlowski-Kordesch E.H. 2010. Lakes. In: James N.P. \& Dalrymple R.W. 2010. Facies Models 4. Geological Association of Canada, $591 p$.

Riding R. 2000. Microbial carbonates: The geological record of calcified bacterial-algal mats and biofilms. Sedimentology, 47(S1):179-214.

Rizzotto G.J., Quadros M.L.E.S., Bahia R.B.C., Dall Igna L.G., Cordeiro A.V. 2004. Folha SC.20-Porto Velho. In: Schobbenhaus C., Gonçalves J.H., Santos J.O.S., Abram M.B., Leão Neto R., Matos G.M.M., Vidotti R.M., Ramos M.A.B., Jesus J.D.A. de. (eds.). Carta Geológica do Brasil ao Milionésimo, Sistema de Informações Geográficas. Programa Geologia do Brasil. CPRM, Brasília. CD-ROM.

Romero G.R., Sanchez E.A.M., Morais L., Boggiani P.C., Fairchild T.R. 2016. Tubestone microbialite association in the Ediacaran cap carbonates in the southern Paraguay Fold Belt (SW Brazil): Geobiological and stratigraphic implications for a Marinoan cap carbonates. Journal of South American Earth Science, 71:172-181.

Santos H.P., Mángano M.G., Soares J.L., Nogueira A.C.R., Bandeira J., Rudnitzki I.D. 2017. Ichnologic evidence of a Cambrian age in the southern Amazon Craton: Implications for the onset of the Western Gondwana history. Journal of South American Earth Sciences, 76:482-488.

Santos J.O.S., Hartmann L.A., Gaudette H.E., Groves D.I., McNaughton N.J., Fletcher I.R. 2000. A new understanding of the Provinces of the Amazon Craton based on integration of field mapping an $\mathrm{U}-\mathrm{Pb}$ and Sm-Nd geochronology. Gondwana Research, 3(4):453-488.

Sato H., Tahata M., Sawaki Y., Maruyama S., Yoshida N., Shu D., Han J., Li Y. Komiya T. 2016. A high-resolution chemostratigraphy of post-Marinoan Cap Carbo using drill core samples in the Three Gorges area, South China. Geoscience Frontiers 7(4):663-671.

Scandalora J.E., Rizzotto G.J., Bahia R.B.C., Quadros M.L.E.S., Amorim J.L., Dall'Igna L.G. 1999. Geologia e Recursos Minerais do Estado de Rondonia: texto explicativo e mapa geológico na escala 1:1.000.000. Programa Levantamentos Geológicos do Brasil. CPRM-Serviço Geológico do Brasil, Brasília, Brasil.

Shields-Zhou G.A., Porter S., Halverson G.P. 2016. A new rock-based definition for the Cryogenian Period (circa 720-635 Ma). Episodes, 39(1):1-8.

Sial A.N., Gaucher C., Misi A., Boggiani P.C., Alvarenga C.J.S., Ferreira V.P., Pimentel M.M., Pedreira J.A., Warren L.V., Fernández-Ramírez R., Geraldes M., Pereira N.S., Chiglino L., Cezario W.S. 2016. Correlations of some Neoproterozoic carbonate-dominated successions in South America based on high-resolution chemostratigraphy. Brazilian Journal of Geology, 46(3):439-488.

Siqueira L.P. 1989. Bacia dos Parecis. Boletim de Geociências da Petrobrás, 3:3-16.

Siqueira L.P. \& Teixeira L.B. 1993. Bacia dos Parecis: nova fronteira exploratória da Petrobrás. In: SBGeof., Congresso Internacional da Sociedade Brasileira de Geofísica, 3, Resumos Expandidos, p. 168- 170.

Soares J.L. \& Nogueira A.C.R. 2008. Depósitos carbonáticos de Tangará da Serra (MT): uma nova ocorrência de capa carbonática neoproterozóica no sul do Cráton Amazônico. Revista Brasileira de Geociências, 38(4):715-729. 
Soares J.L., Nogueira A.C.R., Domingos F., Riccomini C. 2013. Synsedimentary deformation and the paleoseismic record in Marinoan cap carbonate of the southern Amazon Craton, Brazil. Journal of South American Earth Sciences, 48:58-72.

Stanevich A.M., Nemerov V.K., Sovetov Y.K., Chatta E.N., Mazukabzov A.M., Perelyaev V.I., Kornilova T.A. 2005. Precambrian microfossil-characterized biotopes from the southern margin of the Siberian craton. Russian Journal of Earth Sciences, 7:1681-1208.

Tassinari C.G. \& Macambira M.J.B. 1999. Geochronological provinces of the Amazonian Craton. Episodes, 22(3):174-182.

Teyssèdre B. 2006. Are the green algae (phylum Viridiplantae) two billion years old?. Carnets de Geologie, 3:1-15.

Vakarelov B.K., Ainsworth R.B., MacEachern J.A. 2012. Recognition of wave-dominated, tide-influenced shoreline systems in the rock record: Variations from a microtidal shoreline model. Sedimentary Geology, 279:23-41.

Vidal G., Palacios T., Gámez-Vintaned J.A., Balda M.A.D., Grant S.W.F. 1994. Neoproterozoic-Early Cambrian geology and paleontology of Iberia. Geological Magazine, 131:729-765.

Walker R.G. 1992. Facies, facies models and modern stratigraphic concepts. In: Walker R.G. \& James N.P. (eds.). Facies models - response to sea-level change. Ontario, Geological Association of Canada, p. 1-14.

Williams G.E., Gostin V.A., Mckirdy D.M., Preiss W.V. 2008. The Elatina glaciation, late Cryogenian (Marinoan Epoch), South Australia: Sedimentary facies and palaeoenvironments. Precambrian Research, 163(3-4):307-331.

Xiao S., Narbonne G.M, Zhou C., Laflamme M., Grazhdankin D.V. Moczydlowska-Vidal M., Cui H. 2016. Towards an Ediacaran Time Scale: Problems, protocols, and prospects. Episodes, 39(4):540-555. 